\title{
Effect of Swietenia macrophylla seeds on normal and alloxan-induced diabetic rats
}

\author{
Maiti A, Dewanjee S and Mandal SC* \\ Pharmacognosy and Phytotherapy Research Laboratory, Division of Pharmacognosy, Department of \\ Pharmaceutical Technology, Jadavpur University, Kolkata - 700032, India
}

\begin{abstract}
SUMMARY
The methanol extract of the seed of Swietenia macrophylla (Meliaceae) seeds were investigated for its hypoglycaemic activity in normal and alloxan induced diabetic rats. Seed extract suspended in aqueous Tween 80 solution, the graded doses were administered to normal and experimental diabetic rats for 10 days. Fasting blood glucose levels, serum lipid profiles and changes in body weight were evaluated in normal rats while the hepatic marker enzymes and liver glycogen levels were evaluated additionally in diabetic rats. The diabetic groups treated with the seed extract were compared with standard drug glibenclamide. The findings showed the significant antidiabetic potential of the extract in ameliorating the diabetic conditions in diabetic rats. The extract also has hypoglycaemic action in normal rats. A toxicity study has been performed for the extract, which revealed that the extract is safe to use even at the doses of $3.2 \mathrm{mg} / \mathrm{kg}$ of body weight orally. The result from the present investigation indicates good correlation between the folk use and scientific investigation.
\end{abstract}

Keys words: Swietenia macrophylla; Alloxan; Antidiabetic

\section{INTRODUCTION}

Diabetes mellitus is a group of disorder with different etiologies and characterized by de-arrangements in carbohydrate, fat and protein metabolism due to insufficiency of insulin secretion or insulin action (Balkau et al., 2000). Uncontrolled hyperglycemia can lead to disturbance in the structure and function of organs (Kuyvenhoven and Meinders, 1999). Hypoglycaemic activity on natural materials is being investigated by many investigators (Nanda et al., 1997) but particular attention is given

*Correspondence: Mandal SC, Pharmacognosy and Phytotherapy Research Laboratory, Division of Pharmacognosy, Department of Pharmaceutical Technology, Jadavpur University, Kolkata-700032, India. Tel: +00913324676316; Fax: +0091-33-28371078.

E-mail: subhashmandal@yahoo.com to that of herbal folk medicines (Skim et al., 1999). In different parts of the world, traditionally plants extracts is used for the treatment of diabetes mellitus (Kapeham, 1997). In Indian system of medicine i.e. in Ayurveda many plants are used by the traditional healers for the treatment of diabetes (Bahijri et al., 1984). Alternative therapy is needed in the countries where access of conventional treatment of diabetes is not adequate (WHO, 1980).

Hyperglycemia can cause oxidative stress, which in turn may result in cellular tissue damage. The harmful influence of diabetes on metabolism of tissues and organs is well known (West, 2000). Many oral hypoglycaemic agents, such as biguanides and sulfonylureas are available along with insulin for the treatment of diabetes mellitus (Holman and Turner, 1991), but these synthetic agents can produce serious 
side effects and in addition they are not suitable for use during pregnancy (Gilman and Goodman, 1985).

Therefore, search for safe and more effective agents has continued to be an important area of active research. Since ancient times, diabetes has been treated orally with several medicinal plants or their extracts based on folklore medicine.

The plant Swietenia macrophylla (Family: Meliaceae) is a beautiful, lofty, evergreen large tree native to tropical America, Mexico and South America usually 30 - $40 \mathrm{~m}$ in height and 3 - $4 \mathrm{~m}$ in girth (Rastogi and Mehrotra, 1990). The seed of S. macrophylla has been reported for its anti-inflammatory, antimutagenecity and antitumor activity (Guevera et al., 1996).

Swietenine, swietenolide (Guha Sircar and Chakraborty, 1951), swietemahonin, khayasin, andirobin, augustineolide, 7-deacetoxy-7-oxogedunin, 6-deoxy swietenine, proceranolide, 6-o-acetyl swietonolide, 2-hydroxy swietenine have been isolated from the seeds of this plant (Motto et al., 1999). The aqueous extract of the seed of Swietenia macrophylla is widely used in Indonesia as folk medicine to cure diabetes (Shigetoshi et al., 1990). The local people of East Midnapore, West-Bengal, India for curing diabetes, traditionally use seed of Swietenia macrophylla.

The present study was undertaken to investigate the antidiabetic potential of methanol extract of seeds of S. macrophylla in normal and alloxan induced diabetic rats.

\section{MATERIALS AND METHODS}

\section{Chemicals and reagents}

All the solvents used were of analytical grade obtained from E-Merck, Mumbai, India; Alloxan was obtained from Sigma Aldrich, U.S.A and Glibenclamide was obtained from Aventis Pharma. Ltd., Goa, India. Biochemical kits used for this experiment purchased from span diagonastic limited, Mumbai, India. Blood glucose levels were measured using a one touch electronic glucometer of Johnson and Johnson Ltd., India.

\section{Plant material}

The seeds of the plant Swietenia macrophylla (Family: Meliaceae) were collected in the month of December 2005 from the district of Midnapore (East), West Bengal, India. The plant was taxonomically identified and authenticated by Botanical Survey of India (Ref. No. CNH/1(64)/2005-Tech.II/697), Sibpur, India. The seeds of Swietenia macrophylla were separated, washed, shed-dried at room temperature, powdered and sieved through 60 meshes. The powder was preserved in an airtight container for further use. A voucher specimen deposited in our herbarium for further use.

\section{Preparation of extract}

The powdered seeds $(1.2 \mathrm{~g})$ were extracted in a soxhlet extraction apparatus with methanol for $20 \mathrm{~h}$. The methanol was evaporated under reduced pressure by rotary vacuum evaporator. The oil part is decanted and a sticky dark brown residue $(80 \mathrm{~g})$ was obtained (Yield, 15\%). This was stored in desiccators and refrigerated at $4{ }^{\circ} \mathrm{C}$ for future use. The methanol extract was dissolved in $2 \% \mathrm{v} / \mathrm{v}$ aqueous Tween 80 solution prior to the experiment and administered orally (p.o.).

\section{Animals}

Swiss albino mice $(20-22 \mathrm{~g})$ and Wistar albino rats $(200-240 \mathrm{~g})$ of either sex were selected for the experiment. The animals were kept under standard conditions of 12:12 $\mathrm{h}$ light and dark cycle in polypropylene cages and fed with standard laboratory diet and water ad libitum. The animals were acclimatized to laboratory condition for seven days before commencement of experiment. All studies were carried out using 6 rats in each group. The University Animal Ethical Committee reviewed the entire animal protocols prior to conducting the experiments.

\section{Toxicity studies}

Acute toxicity relating to the determination of $\mathrm{LD}_{50}$ value was performed with different doses of the 
extract by an up-and-down staircase method as described by (Ghosh, 1984). The rats were observed continuously for $2 \mathrm{~h}$ for behavioral, neurological and autonomic profiles and after a period of 24 and $72 \mathrm{~h}$, for any lethality or death (Turner, 1965).

\section{Blood collection}

Bloods was withdrawn from the rats by tail snipping and the blood glucose levels were determined using one touch glucometer.

\section{Determination of blood glucose levels}

Blood glucose levels were measured using a one touch electronic glucometer of Johnson and Johnson Ltd., India.

\section{Oral glucose tolerance test}

The oral glucose tolerance test was performed in overnight fasted $(18 \mathrm{~h})$ normal rats. Rats were divided into three groups $(n=6)$. First group received aqueous $2 \% \mathrm{v} / \mathrm{v}$ Tween 80 solution $(1 \mathrm{ml} / \mathrm{kg}$, p.o.) and served as normal. Whereas second and third group received methanol extract of $S$. macrophylla seed (MESM) at the dose level of 200 and $300 \mathrm{mg} / \mathrm{kg}$, p.o. respectively. Glucose $(2 \mathrm{~g} / \mathrm{kg})$ was fed orally, $30 \mathrm{~min}$ prior to the administration of extracts (Bonnerweir, 1988). Blood glucose level was determined by one touch glucometer at 0,60 and $120 \mathrm{~min}$ of extract administration.

\section{Effect of MESM on normal blood glucose level}

Rats were divided into four groups $(n=6)$ and fasted for $18 \mathrm{~h}$ before the experiment. First group received the control vehicle $2 \% \mathrm{v} / \mathrm{v}$ aq. Tween 80 solution (1 ml/kg, p.o.). MESM (200 and $300 \mathrm{mg} / \mathrm{kg}$, p.o.) were administered to second and third groups respectively. The fourth group received the standard drug glibenclamide $(10 \mathrm{mg} / \mathrm{kg}$, p.o.) for assessing the comparative pharmacological significance (Bhaskara et al., 2002). The plasma glucose concentration was determined at 1, 4, 8, 10 and $12 \mathrm{~h}$ after drug (MESM) administration by one touch glucometer.

\section{Effect of MESM on alloxan induced diabetic rats}

The rats were made hyperglycemic by a single dose of intraperitoneal injection with alloxan (120 $\mathrm{mg} / \mathrm{kg}$ ) (Bhaskara et al., 2002). $48 \mathrm{~h}$ after the injection, blood glucose concentration in all the surviving rats were estimated. Rats that were exhibiting plasma glucose concentration of $250-350 \mathrm{mg} / \mathrm{dl}$ were considered to be diabetic and were used for the experiment (Dhanabal et al., 2005). Rats were divided into four groups $(n=6)$ and fasted for $18 \mathrm{~h}$ before the experiment. First group received the control vehicle $2 \% \mathrm{v} / \mathrm{v}$ aq. Tween 80 solution $(1$ $\mathrm{ml} / \mathrm{kg}$, p.o.). MESM (200 and $300 \mathrm{mg} / \mathrm{kg}$, p.o.) were administered to second and third groups respectively. The fourth group received the standard drug glibenclamide $(10 \mathrm{mg} / \mathrm{kg}$, p.o.) and the blood glucose levels were estimated in a similar manner.

\section{Determination of several biochemical parameters of diabetes}

On 10th day animals were sacrificed, blood collected from carotid artery and serum was separated within 30 min of the collection for determination of different biochemical parameters such as cholesterol, triglycerides, serum glutamate oxaloacetate transaminase (SGOT), serum glutamate pyruvate transaminase (SGPT) and alkaline phosphatase (ALP). Livers were collected for determination of liver glycogen level.

\section{Statistical analysis}

All results are expressed as the mean \pm S.E.M. The results were analysed for statistical significance by one - way analysis of variance (ANOVA) followed by Dunnett's test using computerized GraphPad InStat version 3.05, Graph pad software, USA.

\section{RESULTS}

In the $\mathrm{LD}_{50}$ determination it has been observed that the extract (MESM) is safe to use in animals orally (at a dose up to $3.2 \mathrm{~g} / \mathrm{kg}$ ) (Table 8). No lethality or any toxic reactions were found up to the end of study period. The extract from 120 min onwards 
Table 1. Effect of MESM on oral glucose tolerance test (OGTT). Values are expressed as mean \pm S.E.M. $(n=6)$

\begin{tabular}{cccc}
\hline & \multicolumn{3}{c}{ Plasma glucose concentration $(\mathrm{mg} / \mathrm{dl})$} \\
\hline Treatment & $0 \mathrm{~min}$ & $60 \mathrm{~min}$ & $120 \mathrm{~min}$ \\
Normal & $80.4 \pm 1.78$ & $105.7 \pm 4.63$ & $98.3 \pm 3.12$ \\
MESM $(200 \mathrm{mg} / \mathrm{kg})$ & $78.4 \pm 2.33$ & $98.7 \pm 4.46$ & $80.2 \pm 1.12$ \\
MESM $(300 \mathrm{mg} / \mathrm{kg})$ & $84.7 \pm 3.15$ & $95.1 \pm 2.21$ & $84.6 \pm 2.37$ \\
\hline
\end{tabular}

Table 2. Effect of Methanol Extract of Swietenia macrophylla (MESM) on Normoglycaemic rats. Values are expressed as mean \pm S.E.M. $(n=6)$. The results were analyzed by ANOVA followed by Dunnett's test. ${ }^{*} P<0.001$, ${ }^{* *} P<0.01,{ }^{* * k} P<0.05$, vs. control. Data in parenthesis indicate \% of inhibition when compared to control.

\begin{tabular}{|c|c|c|c|c|c|c|}
\hline \multirow{3}{*}{ Treatment } & \multirow{3}{*}{$\begin{array}{c}\text { Dose } \\
\text { (mg/kg, p.o.) }\end{array}$} & \multicolumn{5}{|c|}{ Plasma glucose concentration $(\mathrm{mg} / \mathrm{dl})$} \\
\hline & & \multicolumn{5}{|c|}{ Time after treatment $(\mathrm{h})$} \\
\hline & & $1 \mathrm{~h}$ & $4 \mathrm{~h}$ & $8 \mathrm{~h}$ & $10 \mathrm{~h}$ & $12 \mathrm{~h}$ \\
\hline Control & $1 \mathrm{ml}$ & $106.3 \pm 3.7$ & $112.33 \pm 3.8$ & $112.67 \pm 3.6$ & $112.83 \pm 3.3$ & $112.00+3.0$ \\
\hline MESM & 200 & $\begin{array}{c}100.33 \pm 3.7^{* \pi *} \\
(5.64)\end{array}$ & $\begin{array}{c}86.66+4.4^{*} \\
(22.85)\end{array}$ & $\begin{array}{c}83.00 \pm 4.0 \\
(26.33)\end{array}$ & $\begin{array}{c}77.00 \pm 4.3^{*} \\
(31.76)\end{array}$ & $\begin{array}{c}72.67 \pm 3.7^{*} \\
(35.12)\end{array}$ \\
\hline MESM & 300 & $\begin{array}{c}97.17 \pm 2.9^{\text {sx }} \\
(8.61)\end{array}$ & $\begin{array}{c}82.33 \pm 2.6^{*} \\
(26.71)\end{array}$ & $\begin{array}{c}80.83 \pm 2.0^{*} \\
(28.26)\end{array}$ & $\begin{array}{c}77.33 \pm 2.7^{*} \\
(31.46)\end{array}$ & $\begin{array}{c}71.67 \pm 4.0^{*} \\
(36.01)\end{array}$ \\
\hline Glibenclamide & 10 & $\begin{array}{c}98.50 \pm 3.9^{* x} \\
(7.36)\end{array}$ & $\begin{array}{c}89.50+3.9^{*} \\
(20.32)\end{array}$ & $\begin{array}{c}82.17 \pm 2.6^{*} \\
(27.07)\end{array}$ & $\begin{array}{c}80.33+3.8^{*} \\
(28.80)\end{array}$ & $\begin{array}{c}73.67 \pm 4.0 \\
(34.22)\end{array}$ \\
\hline
\end{tabular}

showed normal blood glucose levels (Table 1).

The hypoglycaemic activity of the MESM was studied in normal rats for $24 \mathrm{~h}$ after oral treatment at the dose levels of 200 and $300 \mathrm{mg} / \mathrm{kg}$. The MESM reduced the blood glucose level significantly $(P<$ 0.001 ) from $4 \mathrm{~h}$ after oral administration, when compared with the control group. It was also noted that the blood glucose-lowering efficacy persisted up to $24 \mathrm{~h}$ after treatment. The effect was comparable to that of the effect produced by the standard drug, glibenclamide $10 \mathrm{mg} / \mathrm{kg}$ (Table 2) and represented in Fig. 1.

The MESM exhibited a significant antihyperglycemic effect in the alloxan induced diabetic rats at 4 days after drug administration and the activity was also persisted up to 10 days. The drug (MESM) at the dose of $300 \mathrm{mg} / \mathrm{kg}$ showed the maximum activity of $41.87 \%(P<0.001)$ reduction in the glucose level was observed at 10 days after drug administration when compared with that of control group. The effect was also comparable with that of effect produced by the standard oral hypoglycaemic drug glibenclamide $(10 \mathrm{mg} / \mathrm{kg}$, 43.50\%) (Table 3)

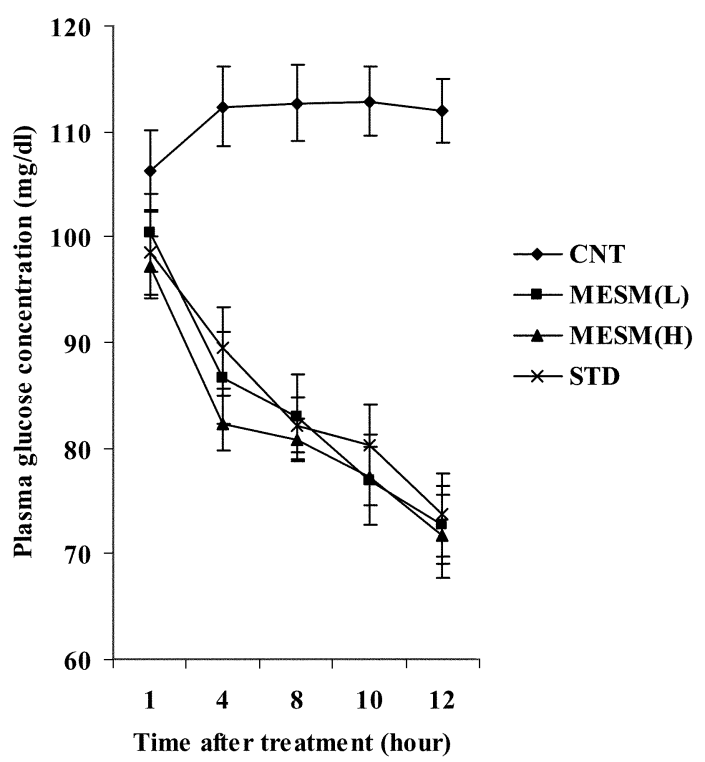

Fig. 1. Effect of MESM on normoglycemic rats.

and represented in Fig. 2.

Significant changes between initial and final body weights were observed in all the extract and standard treated groups (Table 4). Serum total cholesterol and triglyceride level were significantly 
Table 3. Effect of Methanol Extract of Swietenia macrophylla (MESM) on alloxan - induced diabetic rats. Values are expressed as mean \pm SEM $(n=6)$. The results were analyzed by ANOVA followed by Dunnett's test. ${ }^{*} P<0.001$ vs. control. Data in parenthesis indicate \% of inhibition when compared to control

\begin{tabular}{ccccccc}
\hline \multirow{2}{*}{ Treatment } & \multirow{2}{*}{$\begin{array}{c}\text { Dose } \\
\end{array}$} & $(\mathrm{mg} / \mathrm{kg}, \mathrm{p} . \mathrm{o})$. & \multicolumn{5}{c}{ Plasma glucose concentration $(\mathrm{mg} / \mathrm{dl})$} \\
\cline { 3 - 6 } & & 1 day & 4 day & 6 day & 8 day & 10 day \\
\hline Control & $1 \mathrm{ml}$ & $296.83 \pm 5.4$ & $295.67 \pm 4.6$ & $305.00 \pm 3.7$ & $305.33 \pm 7.1$ & $297.33 \pm 2.8$ \\
\hline \multirow{2}{*}{ MESM } & \multirow{2}{*}{200} & $278.17 \pm 4.3^{*}$ & $247.83 \pm 2.3^{*}$ & $227.50 \pm 4.5^{*}$ & $210.33 \pm 4.6^{*}$ & $190.00 \pm 4.6^{*}$ \\
& & $(6.29)$ & $(16.18)$ & $(25.41)$ & $(31.11)$ & $(36.10)$ \\
\hline \multirow{2}{*}{ MESM } & \multirow{2}{*}{300} & $257.33 \pm 5.2^{*}$ & $220.17 \pm 2.3^{*}$ & $204.17 \pm 4.0$ & $185.00 \pm 6.5^{*}$ & $172.83 \pm 3.7^{*}$ \\
& \multirow{2}{*}{10} & $(13.31)$ & $(25.54)$ & $(33.06)$ & $(39.41)$ & $(41.87)$ \\
\hline \multirow{2}{*}{ Glibenclamide } & \multirow{2}{*}{10} & $(6.45)$ & $(24.47)$ & $(35.03)$ & $(40.88)$ & $(43.50)$ \\
\hline
\end{tabular}



Fig. 2. Effect of MESM on alloxan - induced diabetic rats. elevated in diabetic group in comparison to control. Supplementation of this extract for 10 days significantly reduces the level (Table 5). Serum glutamate pyruvate transaminase, serum glutamate oxaloacetate transaminase and alkaline phosphate level were elevated in diabetic rats. But with the treatment with this extract for 10 days resettled a significant diminution of these parameters and resettled towards the control level (Table 6). There is an elevation in levels of hepatic glycogen in alloxan-diabetic rats, after S. macrophylla treatment. Whether in standard group an increased level of liver glycogen also observed in (Table 7). The table 5, 6 and 7 are also represented in Fig. 3.

\section{DISCUSSION}

The aim of the present study was to investigate the antidiabetic effect of $S$. macrophylla seed in alloxaninduced diabetes rats. Our results show that the

Table 4. Effect of MESM on changes in body weight in rats. Values are expressed as mean \pm S.E.M. $(n=6)$.

\begin{tabular}{lcc}
\hline Treatment & Initial $(\mathrm{g})$ & Final $(\mathrm{g})$ \\
\hline Normal Control & $204.62 \pm 6.42$ & $210.21 \pm 3.25$ \\
Normal + MESM $(200 \mathrm{mg} / \mathrm{kg})$ & $209.78 \pm 7.36$ & $210.00 \pm 9.23$ \\
Normal + MESM $(300 \mathrm{mg} / \mathrm{kg})$ & $208.24 \pm 4.57$ & $216.46 \pm 8.13$ \\
Diabetic Control & $228.51 \pm 8.37$ & $160.70 \pm 9.11$ \\
Diabetic + MESM (200 mg/kg) & $220.32 \pm 4.73$ & $191.49 \pm 8.85$ \\
Diabetic + MESM (300 mg/kg) & $222.22 \pm 7.14$ & $208.17 \pm 8.19$ \\
Diabetic + Std. (Glibenclamide) & $221.37 \pm 9.46$ & $208.05 \pm 8.27$ \\
\hline
\end{tabular}


Table 5. Effect of MESM on serum lipid profile in rats. Values are expressed as mean \pm S.E.M. $(n=6)$. The results were analyzed by ANOVA followed by Dunnett's test. ${ }^{*} P<0.05$ vs. control.

\begin{tabular}{lcc}
\hline Treatment & Cholesterol $(\mathrm{mg} / \mathrm{dl})$ & Triglycerides $(\mathrm{mg} / \mathrm{dl})$ \\
\hline Normal Control & $59.46 \pm 1.27$ & $61.57 \pm 2.11$ \\
Normal + MESM $(200 \mathrm{mg} / \mathrm{kg})$ & $61.22 \pm 1.05$ & $61.34 \pm 3.29$ \\
Normal + MESM $(300 \mathrm{mg} / \mathrm{kg})$ & $60.31 \pm 1.20$ & $62.08 \pm 2.76$ \\
\hline Diabetic Control & $104.29 \pm 8.54$ & $102.13 \pm 5.43$ \\
Diabetic + MESM (200 mg/kg) & $82.72 \pm 3.45^{*}$ & $77.26 \pm 4.38^{*}$ \\
Diabetic + MESM (300 mg/kg) & $62.07 \pm 2.12^{*}$ & $67.22 \pm 3.54^{*}$ \\
Diabetic + Std. (Glibenclamide) & $61.28 \pm 2.06^{*}$ & $56.77 \pm 2.20^{*}$ \\
\hline
\end{tabular}

Table 6. Effect of MESM on liver marker enzyme profile in rats. Values are expressed as mean + SEM $(n=6)$. The results were analyzed by ANOVA followed by Dunnett's test. ${ }^{*} P<0.05$ vs. control

\begin{tabular}{lrcc}
\hline Treatment & SGOT (IU/L) & SGPT (IU/L) & ALP (KA Units) \\
\hline Normal & $20.20 \pm 1.26$ & $26.18 \pm 1.27$ & $3.24 \pm 0.16$ \\
Diabetic Control & $116.24 \pm 6.08$ & $80.61 \pm 3.43$ & $7.92 \pm 0.55$ \\
Diabetic + MESM (200 mg/kg) & $77.84 \pm 4.62^{*}$ & $62.44 \pm 3.02^{*}$ & $5.19 \pm 0.42^{*}$ \\
Diabetic + MESM (300 mg/kg) & $58.24 \pm 3.29^{*}$ & $38.33 \pm 3.12^{*}$ & $4.23 \pm 0.12^{*}$ \\
Diabetic + Std. (Glibenclamide) & $60.11 \pm 2.82^{*}$ & $41.70 \pm 2.71^{*}$ & $4.01 \pm 0.66^{*}$ \\
\hline
\end{tabular}

Table 7. Effect of MESM on liver glycogen level in rats. Values are expressed as mean \pm S.E.M. $(n=6)$. The results were analyzed by ANOVA followed by Dunnett's test. ${ }^{*} P<0.05$ vs. control.

\begin{tabular}{lc}
\hline Treatment & $\begin{array}{c}\text { Liver glycogen } \\
(\mathrm{mg} / \mathrm{g})\end{array}$ \\
\hline Diabetic Control & $5.26 \pm 0.13$ \\
Diabetic + MESM (200 mg/kg) & $7.29 \pm 0.09^{*}$ \\
Diabetic + MESM (300 mg/kg) & $9.87 \pm 0.47^{*}$ \\
Diabetic + Std. (Glibenclamide) & $10.13 \pm 0.62^{*}$ \\
\hline
\end{tabular}

methanol extract of $S$. macrophylla seeds reduces the blood glucose level in normal, glucose-loaded and alloxan induced diabetic rats.

It is observed that the blood glucose level is reduced in normal rats and the glucose tolerance in normal rats also significantly improves by the oral administration of $S$. macrophylla seed extract. The antihyperglycaemic action of $S$. macrophylla may be for these possible mechanisms.

The insulin producing beta cells of pancreas is destroyed by the induction of alloxan (Zarrow et al., 1964). In vitro alloxan causes the induction of cell necrosis and selectively toxic to pancreatic beta cells (Jorns et al., 1997). The cytotoxic action of

Table 8. Determination of median lethal dose (MLD) of the methanol extract of MESM administered orally

\begin{tabular}{cccccc}
\hline Treatment & $\begin{array}{c}\text { Dose } \\
(\mathrm{mg} / \mathrm{kg} \text {, p.o. })\end{array}$ & $\begin{array}{c}\text { Number of } \\
\text { animals used }\end{array}$ & $\begin{array}{c}\text { Number of } \\
\text { survival }\end{array}$ & $\begin{array}{c}\text { Number } \\
\text { of death }\end{array}$ & $\begin{array}{c}\text { MLD } \\
\left(\mathrm{LD}_{50}\right)\end{array}$ \\
\hline Control & - & 10 & 10 & 0 & \\
MESM & 100 & 10 & 10 & 0 & 0 \\
& 200 & 10 & 10 & 0 & \\
400 & 10 & 10 & 0 & \\
& 10 & 10 & 0 & \\
& 1000 & 10 & 10 & 0 & $>3.2 \mathrm{~g} / \mathrm{kg}$ \\
\hline
\end{tabular}




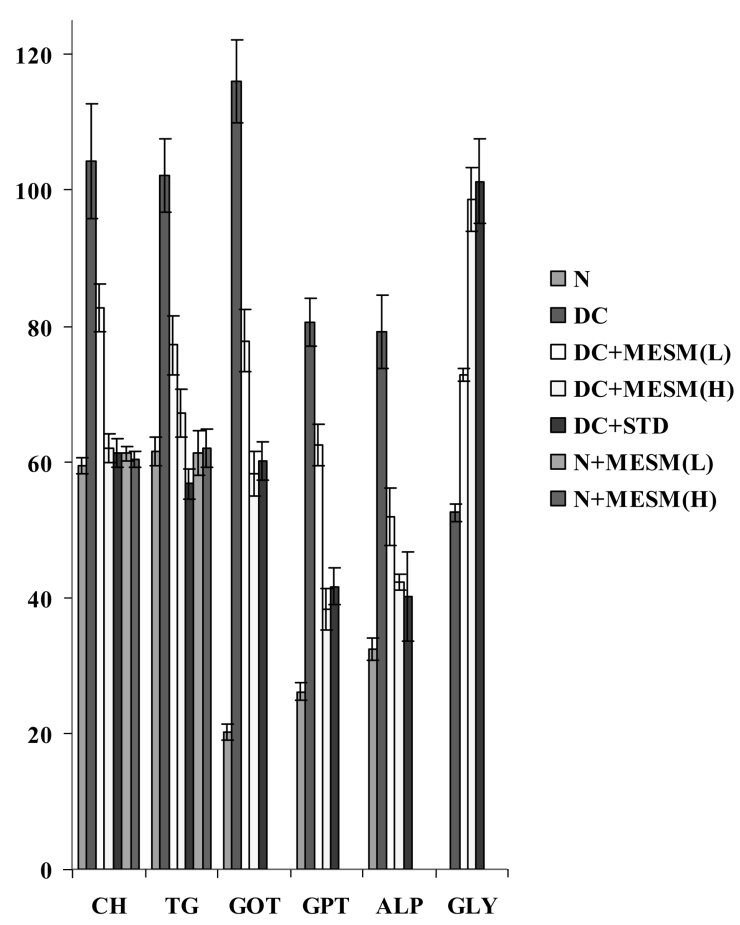

Fig. 3. Effect of MESM on serum lipid profile, liver marker enzyme profile and liver glycogen level in rats. Unit of ALP in graph expressed in KA units multiplied by 10 and GLY in mg/g multiplied by 10 . CH: Cholesterol; TG: Triglyceride; GOT: Glutamate oxaloacetate transaminase; GPT: Glutamate pyruvate transaminase; ALP: Alkaline phosphatase; GLY: Glycogen.

alloxan is mediated by reactive oxygen species, which causes increase in cytosolic calcium concentration, leading to a rapid destruction of beta cells (Szkudelski, 2001).

We showed that the methanol extract from the seeds of S. macrophylla (MESM, 200 and $300 \mathrm{mg} / \mathrm{kg}$ ), administered orally for 10 days, produced significant decrease $(41.87 \%$ for $300 \mathrm{mg} / \mathrm{kg})$ in plasma glucose in the model of alloxan-induced diabetes in rats, by comparing the results after the MESM treatment with comparable to that of standard oral hypoglycaemic agent glibenclamide (43.50\% for 10 $\mathrm{mg} / \mathrm{kg}$ ). A more pronounced effect $(25.54 \%$ reduction in blood glucose level) was observed after a shorter period (4 days) of treatment with the higher dose of MESM $(300 \mathrm{mg} / \mathrm{kg})$ to that of standard drug glibenclamide (24.47\%). The alloxan-induced diabetic rats, the extract was found to produce a pronounced reduction in blood sugar level that became significant after about 4 day and persisted until 10 day. This effect was dose dependent. However, MESM also had hypoglycaemic action in normal rats $(36.01 \%$ after $12 \mathrm{~h})$. This action may be due to the stimulation of the residual pancreatic mechanism, probably by increasing peripheral utilisation of glucose (Erah et al., 1996).

Besides, no significant decrease in blood sugar level was detected in diabetic animals administered with $2 \% \mathrm{v} / \mathrm{v}$ Tween 80 solution, for the same period of time (control). Although the alloxan group (control) presented a dramatic body weight reduction, weight losses were lower in the alloxan plus MESM-treated group, indicating another potential benefit of MESM.

Impairment of liver glycogen synthesis in diabetic rats has reported by Huang (2000). This may be due to lack of or resistance to insulin, which is essential for the activation of glycogen synthase system. The significant increase of liver glycogen level by treatment of this extract in diabetic rats may be due to the reactivation of glycogen synthase system. Diabetes is associated with hyperlipidemia (Pepato et al., 2003). Diabetes induced lipidemia is attributed to excess mobolisation of $f \backslash$ at from the adipose due to the under utilisation of glucose (Krishna kumar et al., 2000). Total cholesterol has been decreased significantly in rats after the extract treatment in diabetic rats. This effect may be due to low activity of cholesterol biosynthesis enzymes and or low level of lipolysis, which are under the control of insulin.

We also measured the serum levels of SGOT, SGPT and ALP, hepatic enzyme markers and showed that these enzyme levels were significantly decreased after MESM treatment in diabetic rats. However, increased levels were observed in controls. Elevated activities of serum aminotransferases are a common sign of liver disease and are more frequently observed among people with diabetes, than in the general population. 
Levels of glucose, triglycerides and total cholesterol were also shown to increase in experimental models of chemically induced diabetes, including that with alloxan. A recent work (De Haro-Hernandez et al., 2004) reported the reversibility of the diabetic state, 12 days after the alloxan injection, as demonstrated by the reduction of glucose and triglyceride concentrations and a positive reaction of the anti-insulin antibodies in the pancreatic tissue. In the present investigation, we followed the hepatic enzymes and lipid profile for 10 days, when the diabetic state was still well maintained.

The experimental data correlate the traditional use of this plant Swietenia macrophylla for diabetes. The exact mechanism of action and the phytochemical(s) responsible for anti diabetic activity is under process.

\section{ACKNOWLEDGEMENTS}

The authors are thankful to All India Council for Technical Education, New-Delhi for the financial support.

\section{REFERENCES}

Bahijri S, Karim A, Karimullah. (1984) Antidiabetic drugs of vegetable origin, A general survey. J. Pharm. Pb. Univ. Lhr. 5, 37-41.

Balkau B, Charles MA, Eschwege E. (2000) Discussion epidemiologigue des nouveaux criteres du diabetes. Mt. Endocrionologie 2, 229-234.

Bhaskara Rao R, Murugesan T, Sinha S, Saha BP, Pal M, Mandal SC. (2002) Glucose lowering efficacy of Ficus racemosa bark extract in normal and alloxan diabetic rats. Phytother. Res. 16, 590-592.

Bonner-weir S. (1988) Morphological evidence of pancreatic polarity of beta cells within islets of Langerhans. Diabetes 37, 616-621.

De Haro-Hernandez R, Cabrera-Munoz L, Mendez JD. (2004) Regeneration of beta cells and neogenesis from small ducts or acinar cells promote recovery of endocrine pancreatic function in alloxan-treated rats. Arch. Med. Res. 35, 114-120.

Dhanabal SP, Sureshkumar M, Ramanathan M, Suresh B. (2005) Hypoglycaemic effect of ethanolic extract of Musa sapientum on alloxan induced diabetes mellitus in rats and its relation with antioxidant potential. J. Herb Pharmacother. 5, 7-19.

Erah PO, Osuide GE, Omogbai EKI. (1996) Hypoglycaemic effect of the extract of Solenostemon monostachys leaves. J. West Afr. Pharm. 10, 21-27.

Ghosh MN. (1984) Toxicity Studies: Fundamentals of Experimental Pharmacology, $2^{\text {nd }}$ ed. Scientific Book Agency, Kolkata, India, pp. 153-158.

Gilman AG, Goodman LS. (1985) The Pharmacological Basis for Therapeutics. Macmillan, New York, pp. 149-151.

Guevera AP, Apilado A, Sakarai H, Kozuka M, Tokunda H. (1996) Anti-inflammatory, antimutagenecity and antitumor activity of mahagony seeds Swietenia macrophylla (Meliaceae). Phill. J. Sc. 125, 271-278.

Guha Sircar SSG, Chakraborty T. (1951) Tetranortriterpenoid from Swietenia macrophylla. J. Ind. Chem. Soc. 28, 207.

Holman RR, Turner RC. (1991) Textbook of Diabetes. Blackwell, Oxford, UK, pp. 407-469.

Huang X, Vaag A, Hanson M, Weng J, Goop L. (2000) Impaired insulin stimulated expression of the glycogen synthase gene in skeletal muscle of Type-2 diabetic patients is aquired rather than inherited. J. Clin. Endo. Metab. 85, 1584-1590.

Jorns A, Munday R, Tiedge M, Lenzen S. (1997) Comparative toxicity of alloxan, N-alkyl-alloxans and ninhydrin to isolated pancreatic islets in vitro. J. Endocrinol. 155, 283-293.

Kapeham, SM. (1997) Drugs from natural products-plant sources in drug discovery, Sciences and Development, Washington D C, American chemical society, pp. 6. Krishnakumar K, Augusti KT, Vijammal Pl. (2000) Hypolipidemic effect of Salacia oblonga Wall. Root bark in streptozotocin diabetes rats. Med. Sci. 28, 65-67.

Kuyvenhoven JP, Meinders AE. (1999) Oxidative stress and diabetic mellitus pathogenesis of longterm complications. Eur. J. Interm. Med. 10, 9-19.

Mootoo BS, Allisha A, Motilal R, Pingal R, Ramlal A, Khan A, Reynolds WF, McLean S. (1999) Limonoids from Swietenia macrophylla and S. aubrevilleana. J. Nat. Prod. 62, 1514-1517.

Nanda SA, Baskandy SAE, Negam SA. (1997) Evaluation of the hypoglycaemic activity of a traditional herbal preparation in male diabetics rats. Fitoterapia 68, 240-244.

Pepato MT, Baviera AM, Vendramini PC, Perez MP, 
Kettelnut IC, Brunett IL. (2003) Cissus sicyoides (Princess wine) in the long term treatment streptozitocin diabetes rats. Biotchnol. Appl. Biochem. 37, 15-20.

Rastogi RP, Mehrotra BN. (1990) Compendium of Indian Medicinal Plants. Vol. I, PID, New-Delhi, India, pp. 397.

Shigetoshi K, Lamik M, Tohru K, Hisao E. (1990) Constituents of the seeds of S. mahagony Jacq, isolation, structure and ${ }^{1} \mathrm{H}$ and ${ }^{13} \mathrm{C}$ NMR signal Assignments of new tetranor triterpenoids related to swietenin and swietenolide. Chem. Pharm. Bull. 38, 639-651.

Skim F, Kayya A, Jaouri JT, Lazrek HB. (1999) Hypoglycaemic activity of Globularia alypum leaves in rats. Fitoterapia 70, 382-389.
Szkudelski T. (2001) The mechanism of Alloxan and Streptozotocin action in $\mathrm{b}$ cells of the rat pancreas. Physiol. Res. 50, 537-546.

Turner MA. (1965) Screening methods in pharmacology, $2^{\text {nd }}$ ed. Academic press. New York, pp. 26.

West IC. (2000) Radicals and oxidative stress in diabetes. Diabet. Med. 17, 171-180.

WHO. (1980) World Health Organization Expert Committee on Diabetes Mellitus, Second report, Technical report series, Geneva, 646.

Zarrow MX, Yochim JM, McCarthy JL. (1964) Experimental Endocrinology: A Source Book of Basic Techniques, Academic Press, New York, pp. 406-409. 